\title{
Spinocerebellar Ataxia Type 6
}

National Cancer Institute

\section{Source}

National Cancer Institute. Spinocerebellar Ataxia Type 6. NCI Thesaurus. Code C142838.

An autosomal recessive spinocerebellar ataxia caused by an expanded CAG repeat in the CACNA1A gene, encoding voltage-dependent P/Q-type calcium channel subunit alpha-1A. It is an almost pure cerebellar syndrome, with onset typically between the ages of 20 to 60. 